\title{
Hubungan Karakteristik Pembimbing Klinik Dengan Keterampilan Klinik Asuhan Persalinan Normal Pada Mahasiswa Program Diploma III Kebidanan
}

\author{
Kurniawati, ${ }^{1}$ Endang Sutedja, ${ }^{2}$ Farid Husin, ${ }^{3}$ Dany Hilmanto, ${ }^{4}$ Firman F. Wirakusumah,,${ }^{5}$ Herman Susanto, ${ }^{6}$ Benny \\ Hasan Purwara, ${ }^{7}$ Yoni Fuadah Syukriani ${ }^{8}$ \\ ${ }^{1}$ Mahasiswa Program Studi Magister Kebidanan Fakultas Kedokteran Universitas Padjadjaran \\ ${ }^{2}$ Departemen Kulit dan Kelamin Fakultas Kedokteran Universitas Padjadjaran \\ ${ }^{3,5,7}$ Departemen Obstetri dan Ginekologi Fakultas Kedokteran Universitas Padjadjaran \\ ${ }^{4,6}$ Departemen Ilmu Kesehatan Anak Fakultas Kedokteran Universitas Padjadjaran \\ ${ }^{8}$ Departemen Kedokteran Forensik Fakultas Kedokteran Universitas Padjadjaran
}

\begin{abstract}
Abstrak
Keterampilan klinik mahasiswa merupakan elemen penting dalam membangun kompetensi lulusan pendidikan bidan. Pencapaian keterampilan klinik mahasiswa di lahan praktik sangat bergantung pada pembimbing klinik. Karakteristik pembimbing klinik yang efektif akan menghasilkan pembelajaran klinik yang efektif. Pembelajaran klinik yang efektif akan mendukung pencapaian keterampilan klinik mahasiswa di lahan praktik.Tujuan penelitian ini untuk menganalisis karakteristik pembimbing klinik yang berhubungan dengan keterampilan klinik mahasiswa dalam asuhan persalinan normal. Penelitian ini merupakan penelitian kuantitatif dengan rancangan penelitian observasional analitik dengan pendekatan potong lintang. Subyek penelitian ini adalah mahasiswa DIII Kebidanan yang sedang praktik PKK III di ruang bersalin RSUD Banjar dan RSUD Tasikmalaya sampai dengan Juni 2013 yang berjumlah 70 orang, dan 28 orang pembimbing klinik. Teknik pengambilan sampel dilakukan secara total sampling.Analisis univariabel dengan distribusi frekuensi, analisis bivariabel dengan uji chi-kuadrat, dan analisis multivariabel dengan regresi logistik.Hasil penelitian menunjukkan bahwa terdapat hubungan karakteristik demografi dengan keterampilan klinik mahasiswa dalam asuhan persalinan normal $(\mathrm{p}=0,022)$. Terdapat hubungan karakteristik kualitas pembimbing klinik dengan keterampilan klinik asuhan persalinan normal $(\mathrm{p}=0,022)$. Variabel pelatihan merupakan faktor paling berperan terhadap keterampilan klinik asuhan persalinan normal $(\mathrm{POR}=15$; IK $95 \%=1.629-138.156)$. Penelitian ini memberikan kesimpulan bahwa terdapat hubungan karakteristik pembimbing klinik dengan keterampilan klinik mahasiswa dalam asuhan persalinan normal. Dengan demikian dalam menentukan lahan praktik harus memperhatikan karakteristik pembimbing klinik yang ada pada lahan praktik.
\end{abstract}

Kata kunci: Demografi, karakteristik, kualitas, keterampilan klinik, pembimbing klinik.

Korespondensi : Cimenyan 2 RT 02 RW 06 Kelurahan Mekarsari Kota Banjar, mobile /HP 085223043644, e-mail bundania22980@gmail.com 
Kurniawati : Hubungan Karakteristik Pembimbing Klinik Dengan Keterampilan Klinik Asuhan Persalinan Normal Pada Mahasiswa Program Diploma III Kebidanan

\title{
Correlation of Clinical Instructor Characteristics with Student Diploma III Midwifery Clinical Skills in the Normal Delivery Care
}

\begin{abstract}
Clinical skills of students is an important element in building competency midwifery education. Clinical instructor influenced in student clinical skills in the clinical practice. Identifying the characteristics of effective clinical instructor is very important, because the characteristics of effective clinical instructor will result in an effective clinical learning . Effective clinical learning will support the achievement of student clinical skills in the clinical practice. This method used is a cross sectional. The subjects were midwifery diploma students who are PKK III practices numbering 70 people, clinical instructor 28 people in a total sampling. Statistic analysis used was chi-square and multivariable logistic regression. The results showed there was relationship of demographic characteristics with student clinical skills $(p=0,022)$. There was relationship of quality characteristic with student clinical skills $(\mathrm{p}=0,022)$ and training variables were most influenced factor with student clinical skills (POR -15,CI 95\%=1.629-138.156). Conclusions of this research, that there was correlation of clinical instructor characteristics with student clinical skills in the care of normal deliveries. Thus the clinical instructor characteristics that influenced in clinical skills students need to be considered.
\end{abstract}

Keywords: Clinical instructor, characteristics, clinical skills, demographic, quality. 
Kurniawati : Hubungan Karakteristik Pembimbing Klinik Dengan Keterampilan Klinik Asuhan Persalinan Normal Pada Mahasiswa Program Diploma III Kebidanan

\section{Pendahuluan}

Pembelajaran klinik merupakan inti dari pendidikan kebidanan. Kegiatan pembelajaran praktik klinik pada program pendidikan bidan adalah suatu proses pembelajaran untuk melatih keterampilan peserta didik dalam memberikan asuhan kebidanan melalui pengalaman nyata yang memerlukan praktik langsung pada pasien. ${ }^{1}$ Beberapa faktor yang memengaruhi proses pembelajaran praktik klinik di lahan praktik diantaranya adalah karakteristik pembimbing klinik, karakteristik mahasiswa, lingkungan pembelajaran, dan perencanaan pendidikan. ${ }^{2}$

Di lahan praktik pembimbing klinik merupakan pusat dari pembelajaran klinik. ${ }^{3}$ Pembimbing klinik mengajarkan keterampilan klinik terutama melalui interaksi dan penanganan pasien secara langsung dan memiliki kontribusi yang signifikan terhadap pemahaman dan kompetensi mahasiswa dalam praktik klinik. Pembimbing klinik bertanggung jawab untuk memastikan mahasiswa belajar dan mendapatkan pengalaman keterampilan klinik, pada saat yang sama pembimbing klinik pun harus memastikan pasien mendapat pelayanan yang berkualitas tinggi dan aman. ${ }^{4}$ Sehingga, diperlukan adanya karakteristik pembimbing klinik yang efektif, agar mahasiswa mendapat pengalaman klinik yang baik dan pasien tetap aman dan selamat. Tujuan dalam penelitian ini adalah untuk menganalisis karakteristik pembimbing klinik yang berhubungan dengan keterampilan klinik mahasiswa dalam asuhan persalinan normal.

\section{Metode}

Penelitian ini menggunakan metode kuantitatif dengan rancangan penelitian observasional analitik dengan pendekatan potong lintang. Populasi dalam penelitian ini adalah seluruh mahasiswa semester VI yang sedang praktik di ruang bersalin RSUD Kota Banjar dan RSUD Tasikmalaya sampai dengan bulan juni 2013sampel sebanyak 70 mahasiswa dan 28 pembimbing klinik di ruang bersalin. Pengumpulan data dilaksanakan pada bulan Junitahun 2013. Jenis data yang digunakan adalah data primer dengan instrumen pengumpulan data menggunakan kuesioner. Data yang terkumpul dilakukan uji analisis chi-square dan regresi logistik.

\section{Hasil}

\section{Hubungan karakteristik demografi pembimbing klinik dengan keterampilan klinik asuhan persalinan normal}

Menganalisis hubungan karakteristik demografi pembimbing klinik dengan keterampilan klinik asuhan persalinan normal dengan menggunakan uji chi-kuadrat, nilai $\mathrm{p}<0,05$ menunjukkan bahwa terdapat hubungan karakteristik demografi pembimbing klinik dengan keterampilan klinik asuhan persalinan normal.

Tabel 1 Hubungan karakteristik demografi pembimbing klinik dengan keterampilan klinik asuhan persalinan normal

\begin{tabular}{|c|c|c|c|}
\hline \multirow{3}{*}{$\begin{array}{c}\text { Karakteristik } \\
\text { demografi }\end{array}$} & \multicolumn{2}{|c|}{$\begin{array}{c}\text { Keterampilan Klinik } \\
\text { Asuhan Persalinan } \\
\text { Normal }\end{array}$} & \multirow[t]{3}{*}{ Nilai $p^{*}$} \\
\hline & $\begin{array}{c}\text { Kurang } \\
\text { Baik }\end{array}$ & Baik & \\
\hline & n $\%$ & $\%$ & \\
\hline
\end{tabular}

\begin{tabular}{lccccc}
\hline $\begin{array}{l}\text { 1. Umur } \\
\text { < 30 Tahun }\end{array}$ & 7 & 100 & 0 & 0 & 0,006 \\
230 Tahun & 7 & 33,3 & 14 & 66,7 & \\
\hline $\begin{array}{l}\text { 2. Lama kerja } \\
\text { < } 5 \text { tahun }\end{array}$ & 9 & 81,8 & 2 & 18,2 & 0.007 \\
$\quad$ 25 Tahun & 5 & 29,4 & 12 & 70,6 & \\
\hline 3. Pendidikan & & & & & \\
$\quad$ D III & 14 & 51,9 & 13 & 48,1 & 1,000 \\
D IV & 0 & 0 & 1 & 100 & \\
\hline 4. Pelatihan & & & & & \\
$\quad$ Ya & 5 & 29,5 & 12 & 70,6 & 0.007 \\
Tidak & 9 & 81,8 & 2 & 18,2 & \\
\end{tabular}

*uji chi kuadrat

Hasil uji statistik pada tabel 1 menunjukkan dari empat variabel karakteristik demografi terdapat tiga variabel karakteristik yang memiliki hubungan dengan keterampilan klinik asuhan persalinan normal, sehingga diperlukan analisis lebih lanjut pada tabel 2 dengan skoring/ pembobotan. 
Kurniawati : Hubungan Karakteristik Pembimbing Klinik Dengan Keterampilan Klinik Asuhan Persalinan Normal Pada Mahasiswa Program Diploma III Kebidanan

2. Hubungan Karakteristik Demografi dan Kualitas Pembimbing Klinik dengan Keterampilan Klinik Asuhan Persalinan Normal

Tabel 2 Hubungan Karakteristik Demografi dan Kualitas Pembimbing Klinik dengan Keterampilan Klinik Asuhan Persalinan Normal

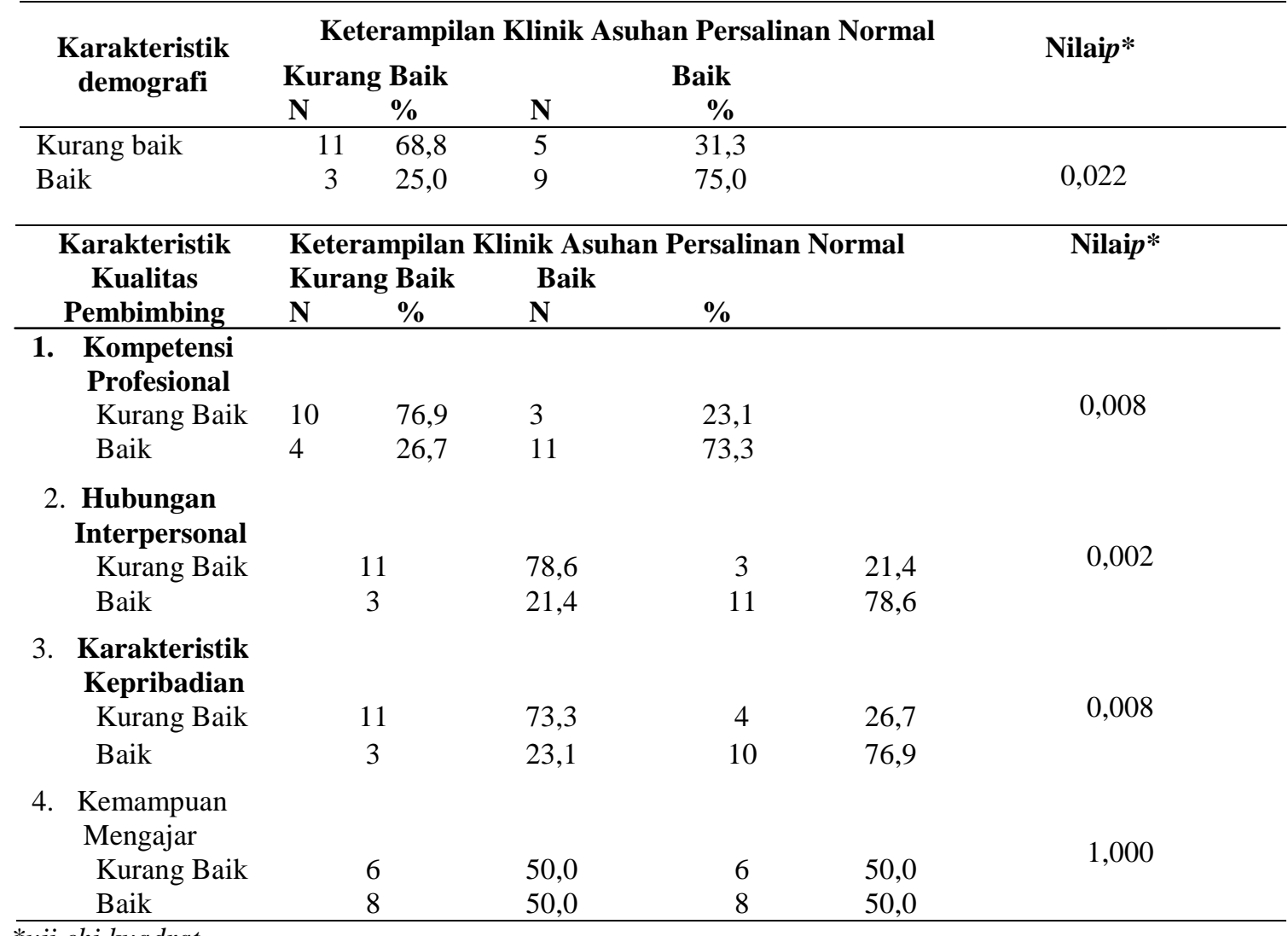

*uji chi kuadrat

Pada tabel 2 dilakukan analisis bivariat dengan menggunakan analisis chi-kuadrat. Berdasarkan hasil analisis bivariat dimana keterampilan klinik asuhan persalinan normal mahasiswa dalam kategori baik, yaitu $66,7 \%$ dibimbing oleh pembimbing klinik dengan umur $\geq 30$ tahun.
Dari empat variabel karakteristik demografi terdapat tiga variabel karakteristik yang memiliki hubungan dengan keterampilan klinik asuhan persalinan normal, kemudian dilakukan analisis bivariat pada tabel dengan menggunakan chikuadrat.

3. Faktor pembimbing klinik yang paling berperan terhadap keterampilan klinik mahasiswa dalam asuhan persalinan normal

Tabel 3 Analisis Multivariabel Karakteristik Pembimbing Klinik Dengan Keterampilan Klinik Asuhan Persalinan Normal

\begin{tabular}{llllll}
\hline \multicolumn{1}{c}{ Model } & \multicolumn{1}{c}{ Variabel } & $\begin{array}{c}\text { Koefisien } \\
\mathbf{B}\end{array}$ & \multicolumn{1}{c}{ S.E (B) } & $\begin{array}{c}\text { Nilai } \\
\mathbf{p}^{*}\end{array}$ & POR (IK 95\%) \\
\hline \multirow{2}{*}{$\begin{array}{l}\text { Model } \\
\text { akhir }\end{array}$} & Umur & -22.024 & $1.369 \mathrm{E} 4$ & .999 & $.000(.000-)$ \\
& Pelatihan & 2.708 & 1.133 & .017 & $15.000(1.629-138.156)$ \\
& Konstanta & -.916 & .837 & .273 & .400 \\
\hline * uji regresi logistik & & & &
\end{tabular}


Hasil uji statistik menunjukkan variabel yang paling berperan dalam keterampilan klinik mahasiswa adalah pelatihan, dengan nilai POR variabel pelatihan sebesar 15 yang berarti pembimbing klinik yang tidak mengikuti pelatihan, memiliki resiko $15 \mathrm{x}$ menjadikan keterampilan klinik asuhan persalinan normal mahasiswa yang dibimbingnya menjadi kurang baik.

\section{Pembahasan}

Siagian mengatakan bahwa semakin meningkatnya usia seseorang maka kedewasaan teknis dan psikologinya semakin meningkat. Ia akan semakin mampu mengambil keputusan, semakin bijaksana, mampu berpikir secara rasional, mengendalikan emosi dan toleran terhadap pendapat orang lain. ${ }^{6}$ Hasil penelitian ini didukung dari hasil wawancara mahasiswa mengenai karakteristik pembimbing klinik yang dapat meningkatkan keterampilan klinik mahasiswa yaitu bahwa mereka membutuhkan pembimbing yang bijaksana dan dapat mengendalikan emosi sehingga mahasiswa merasa nyaman dalam melaksanakan tindakan. Sementara hasil yang berbeda terlihat dari penelitian Bambang yang menunjukan ada hubungan negatif usia guru dengan motivasi kerja guru dalam melaksanakan tugas. Semakin tinggi usia,semakin menurun motivasi kerjanya dalam melaksanakan tugas dan secara tidak langsung berpengaruh terhadap keefektifan kerjanya. ${ }^{7}$ Penelitian dari Yuyun Tafwidah juga menunjukkan hasil tidak terdapat hubungan antara umur perawat dengan tingkat keterlaksanaan kegiatan perkesmas. ${ }^{8}$ Dalam penelitiannya menyertakan pendapat dari Robbins (2001) yang menyatakan kinerja akan menurun seiring dengan bertambahnya usia.

Hasil penelitian ini terlihat bahwa umur pembimbing klinik di RSUD Kota Banjar dan RSUD Kota Tasikmalaya dengan kisaran umur 25 hingga 54 tahun dan paling banyak pembimbing klinik berusia $\geq 30$ tahun. Rentang umur pembimbing klinik termasuk pada usia produktif sehingga adanya semangat dan produktifitasnya baik, termasuk dalam bimbingan terhadap mahasiswa.

Hasil analisis bivariat menunjukkan keterampilan klinik asuhan persalinan normal mahasiswa dalam kategori baik, yaitu 70,6\% dibimbing oleh pembimbing klinik dengan lama kerja $\geq 5$ tahun. Hasil penelitian ini sesuai dengan teori yang dikemukakan oleh Siagian (dalam Adji 2002) menyatakan bahwa semakin lama seseorang bekerja dalam suatu organisasi semakin tinggi pula produktifitasnya, karena semakin berpengalaman serta memiliki keterampilan tinggi dalam menyelesaikan tugas. ${ }^{6}$ Pembimbing klinik yang sudah lama bekerja akan memiliki keterampilan dalam membimbing dan mengarahkan mahasiswa untuk mencapai keterampilan kliniknya. Menurut Anderson dalam Yuliza, pada umumnya seseorang yang sudah lama bekerja pada bidang tugasnya, makin mudah memahami tugasnya tersebut, sehingga memberi peluang orang tersebut untuk meningkatkan prestasi serta beradaptasi dengan lingkungan dimana ia berada. Lama kerja dapat meningkatkan motivasi untuk mencapai kinerja tinggi. ${ }^{9}$ Hasil penelitian ini tidak sejalan dengan pendapat Samsul Alam lama kerja seseorang tidak memengaruhi keterampilan klinik mahasiswa yang dibimbingnya dikarenakan lama kerja yang masih baru atau segar belum mengalami kejenuhan dalam dirinya, sementara semakin senior seseorang perawat semakin jauh dari pasien dan lingkup pekerjaannya lebih berkaitan dengan manajemen. ${ }^{10}$

Dari hasil penelitian terlihat lama kerja pembimbing klinik di ruang bersalin minimal 2 tahun dan paling lama adalah 25 tahun. Berdasarkan hasil penelitian dan teori yang ada, peneliti berpendapat bahwa ada hubungan antara lama kerja pembimbing klinik dengan keterampilan klinik asuhan persalinan normal pada mahasiswa DIII Kebidanan.Hal ini dikarenakan lama kerja seseorang semakin berpengalaman dan memiliki keterampilan yang tinggi dalam menyelesaikan tugasnya. Diantara tugas pembimbing klinik salah satunya adalah membimbing mahasiswa mendapatkan keterampilan kliniknya bisa tercapai.

Tingkat pendidikan diartikan sebagai pendidikan formal yang dicapai atau diperoleh di bangku sekolah. Pendidikan formal yang ditempuh merupakan modal penting karena dengan pendidikan seseorang mempunyai kemampuan dan dapat mudah mengembangkan diri dalam bidang kerjanya. ${ }^{7}$ Hasil analisis bivariat pada penelitian ini variabel pendidikan pembimbing klinik tidak berpengaruh terhadap keterampilan klinik asuhan persalinan normal pada mahasiswa DIII Kebidanan. Hasil penelitian ini dapat terjadi dimungkinkan karena proporsi tingkat pendidikan yang dimiliki 
pembimbing klinik tidak seimbang atau dapat dikatakan homogen 96,42\% pembimbing klinik berpendidikan DIII Kebidanan. Pada saat penelitian dilaksanakan, telah terjadi rotasi dan promosi di ruang bersalin RSUD Tasikmalaya, bidan yang bertugas di ruang bersalin dengan latar belakang pendidikan DIV Kebidanan, dirotasi ke ruang nifas dan ruang ginekologi menjadi kepala ruangan dan wakil kepala ruangan, dan beberapa orang menjadi pejabat struktural. RSUD Kota Banjar juga terjadi rotasi dan promosi bidan yang bertugas di ruang bersalin dengan latar belakang pendidikan DIV Kebidanan, di rotasi ke ruang nifas menjadi kepala ruangan dan wakil kepala ruangan. Tingkat pendidikan pembimbing klinik merupakan salah satu faktor yang dapat memengaruhi keterampilan klinik mahasiswa sesuai dengan pendapat Limisran yang menyatakan bahwa pendidikan formal dapat meningkatkan pola fikir dan pola tindak pembimbing klinik, dalam melakukan pekerjaan bimbingan. ${ }^{11}$

Pelatihan merupakan suatu kegiatan pembelajaran dalam upaya meningkatkan pengetahuan, ketrampilan dan memperbaiki kinerja pekerja pada pekerjaan tertentu yang menjadi tanggung jawabnya atau berkaitan dengan pekerjaan menjadi lebih baik dan efektif. Hasil analisis bivariat menunjukkan keterampilan klinik asuhan persalinan normal mahasiswa yang dibimbing oleh pembimbing klinik yang telah mengikuti pelatihan $68,8 \%$ memiliki keterampilan klinik yang baik.

Hal ini sejalan dengan hasil penelitian Limisan yang menunjukkan adanya pengaruh pelatihan terhadap kinerja pembimbing klinik. ${ }^{11}$ Teori yang ditulis Samsudin (2006) yang menyatakan bahwa pelatihan merupakan serangkaian aktivitas yang dirancang meningkatkan pengetahuan, kemampuan, ketrampilan, sikap dan kinerja sumber daya manusia. Aktivitas ini mengajarkan keahlian baru, memperbaiki keahlian yang ada, dan memengaruhi sikap dan tanggung jawab para karyawan. ${ }^{12}$

Dari hasil penelitian dan teori yang ada, peneliti berpendapat bahwa ada hubungan antara pelatihan dengan keterampilan klinik asuhan persalinan normal.Pelatihan lebih berkaitan dengan peningkatan keterampilan pada suatu pekerjaan atau tanggung jawab tertentu. Pelatihan merupakan cara terpadu dan sistematis pada tuntutan kerja aktual, dengan penekanan pada pengembangan pengetahuan, keterampilan dan kemampuan/ability. Sehingga diharapkan semakin sering seseorang pelatihan, semakin tinggi pula pengetahuan, keterampilan dan kemampuan/abilitynya.

Kompetensi profesional adalah kemampuan yang harus dimiliki dalam perencanaan dan pelaksanaan proses pembelajaran mengarahkan kegiatan belajar siswa untuk mencapai tujuan pembelajaran. Kompetensi profesional yang harus dimiliki seorang pembimbing klinik diantaranya tertarik dalam perawatan pasien, berlaku teori dalam praktik klinik, panutan bagi siswa, terampil dalam teknik keperawatan, memiliki pengetahuan profesional, menjelaskan dan menunjukkan teknik-teknik baru. Hasil analisis bivariat yaitu menunjukkan keterampilan klinik asuhan persalinan normal mahasiswa dalam kategori baik 73,3\% dibimbing oleh pembimbing klinik yang memiliki karakteristik kompetensi profesional dengan kategori baik. Hasil penelitian ini sejalan dengan hasil penelitian Yeti Resnayati tentang Faktor determinan pengalaman belajar klinik keperawatan medikal bedah pada mahasiswa DIII Keperawatan, menyatakan bahwa faktor yang paling berhubungan erat dengan pengalaman belajar klinik adalah ketersediaan perawat profesional yang dapat dijadikan model peran atau panutan untuk ditiru oleh mahasiswa (p Wald $=0,01$ dan OR23,64). ${ }^{13}$

Hasil penelitian ini mendukung teori WHO (dalam Notoatmodjo,1997) yang menyatakan bahwa salah satu faktor penting dalam pembentukan perilaku seseorang adalah adanya panutan (personal references) dalam melakukan tindakan-tindakan profesional yang dilandasi kultur,dan nilai yang berakar pada komunitas profesinya. $^{13}$

Karakteristik hubungan interpersonal diantaranya tidak mengintervensi kerja siswa, memberikan umpan balik untuk perbaikan siswa, memecahkan masalah dengan siswa, memperlakukan mahasiswa sebagai orang dewasa, memberikan kritik konstruktif, menghindari sikap otoriter dan mendominasi, tidak mengecam siswa di depan orang lain, memberikan siswa kesempatan untuk menjelaskan, memiliki hubungan yang baik dengan anggota tim kesehatan lainnya. Hasil uji statistik chi square didapatkan nila $\mathrm{p}=0,002$ sehingga Hipotesis nol (Ho) ditolak, Hipotesis alternatif (Ha) diterima. Ada hubungan karakteristik kualitas pembimbing klinik yang 
Kurniawati : Hubungan Karakteristik Pembimbing Klinik Dengan Keterampilan Klinik Asuhan Persalinan Normal Pada Mahasiswa Program Diploma III Kebidanan

dilihat dari hubungan interpersonal dengan keterampilan klinik asuhan persalinan normal pada mahasiswa DIII Kebidanan.

Hasil penelitian ini sejalan dengan penelitian Elfi Syahreni yang menyatakan bahwa hasil pembelajaran yang baik akan tercapai apabila mahasiswa telah memperoleh arahan, umpan balik yang tepat terhadap kegiatan, sikap dan penampilan dan laporan yang telah disampaikan mahasiswa selama proses pembelajaran. Hubungan yang harmonis antara pembimbing dan mahasiswa selama proses pembelajaran menjadi bermakna terhadap keberhasilan mahasiswa dalam praktik klinik, dan hal ini sesuai dengan pernyataan Ferguson (1996) yang menyatakan bahwa hubungan antara pembimbing dan mahasiswa sangat penting dalam keberhasilan praktik klinik. ${ }^{14}$

Karakteristik kepribadian yaitu memiliki kesabaran dan dapat mengontrol marah serta menunjukkan sikap kooperatif, memperlakukan siswa dengan tulus dan obyektif, memiliki sikap antusias dalam mengajar klinis, mampu mengelola insiden yang dibuat oleh mahasiswa dengan baik, menghindari omelan terhadap kesalahan siswa, memiliki empati terhadap siswa, menerima pendapat dengan wajar, menghormati hak privasi mahasiswa, menerima perbedaan individu pada siswa, menghindari penilaian yang bersifat subyektif terhadap siswa.

Berdasarkan hasil penelitian, diketahui bahwa pembimbing klinik sebagian besar memiliki karakteristik kepribadian dalam kategori baik. Hasil analisis bivariat menunjukkan keterampilan klinik asuhan persalinan normal mahasiswa dalam kategori baik, yaitu $76,9 \%$ dibimbing oleh pembimbing klinik yang memiliki karakteristik kepribadian dengan kategori baik. Hasil uji statistik chi square didapatkan nilai $\mathrm{p}=0,008$, sehingga Hipotesis nol (Ho) diolak, Hipotesis Alternatif (Ha) diterima. Ini berarti ada hubungan karakteristik kualitas pembimbing klinik yang dilihat dari karakteristik kepribadian dengan keterampilan klinik asuhan persalinan normal pada mahasiswa DIII Kebidanan.

Dari hasil pertanyaan terbuka, sebagian besar mahasiswa memiliki harapan pembimbing klinik yang ramah, mudah diakses oleh mahasiswa serta memiliki perhatian terhadap mahasiswa. Menurut Firoozeh Firoozehchian, faktor-faktor yang berpengaruh terhadap pembelajaran klinik adalah karakteristik pembimbing klinik, lingkungan pembelajaran, perencanaan pendidikan dan karakteristik mahasiswa. ${ }^{2}$

Nicklin dan Kenworthy dalam Teaching and Assesing in Nursing Practice yang menggambarkan bahwa ada hubungan saling memengaruhi antara 4 faktor dalam praktik klinik mahasiswa yaitu pasien, tempat praktik, perawat di lahan praktik dan karakteristik mahasiswa itu sendiri. ${ }^{13}$

Kemampuan dalam mengajar adalah kemampuan membimbing mahasiswa, merencanakan bahan bimbingan (plan instruction) dalam tiaptiap bagian atau pokok bahasan dan tujuan yang harus dicapai, mengevaluasi proses bimbingan. Berdasarkan hasil penelitian dilihat dari hasil analisis bivariabel tampak hasil yang seimbang antara keterampilan klinik kurang baik dan baik. Hasil uji statistik chi square didapatkan nilai $\mathrm{p}=1,000$, sehingga Hipotesis nol (Ho) diterima, Hipotesis Alternatif (Ha) ditolak. Ini berarti tidak ada hubungan karakteristik kualitas pembimbing klinik yang dilihat dari kemampuan mengajar dengan keterampilan klinik asuhan persalinan normal pada mahasiswa DIII Kebidanan.

Hasil penelitian ini sejalan dengan penelitian Setyaningsih tentang Penilaian Efektifitas Pengajaran Klinik (kemampuan mengajar) Pembimbing Klinik di RS Dr.R. Koesma Tuban yang menyatakan bahwa tidak terdapat perbedaan penilaian kemampuan mengajar pembimbing klinik tentang efektifitas pengajaran klinik. ${ }^{15}$

Menurut Firoozeh Firoozehchian, faktorfaktor yang berpengaruh terhadap pembelajaran klinik adalah karakteristik pembimbing klinik, lingkungan pembelajaran, perencanaan pendidikan dan karakteristik mahasiswa. ${ }^{2}$ Nicklin dan Kenworthy dalam Teaching and Assesing in Nursing Practice yang menggambarkan bahwa ada hubungan saling memengaruhiantara 4 faktor dalam praktik klinik mahasiswa, yaitu pasien, tempat praktik, perawat di lahan praktik dan karakteristik mahasiswa itu sendiri. ${ }^{13}$

Berdasarkan hasil penelitian dan teori yang ada, peneliti mengambil simpulan bahwa karakteristik kualitas pembimbing klinik dilihat dari kemampuan mengajar tidak berhubungan dengan keterampilan klinik mahasiswa dalam asuhan persalinan normal. Terdapat hubungan antara karakteristik kualitas pembimbing klinik dengan keterampilan klinik mahasiswa dalam asuhan persalinan normal. Karakteristik pembimbing klinik hanya salah satu faktor yang memengaruhi ketrampilan klinik mahasiswa, Hal 
Kurniawati : Hubungan Karakteristik Pembimbing Klinik Dengan Keterampilan Klinik Asuhan Persalinan Normal Pada Mahasiswa Program Diploma III Kebidanan

ini perlu diperhatikan dalam keberhasilan pembelajaran klinik khususnya tercapainya keterampilan klinik dipengaruhi oleh beberapa faktor yaitu karakteristik mahasiswa itu sendiri, ketersediaan pembimbing klinik profesional yang dapat dijadikan model peran, lingkungan pembelajaran, ketersediaan pasien dan perencanaan pendidikan.

Variabel yang paling berperan dalam keterampilan klinik mahasiswa adalah pelatihan.Hal ini sejalan dengan pendapat Gomes (1999) mengemukakan definisi pelatihan adalah suatu kegiatan pembelajaran dalam upaya meningkatkan pengetahuan dan ketrampilan untuk memperbaiki kinerja pekerja pada suatu pekerjaan tertentu yang menjadi tanggung jawabnya atau berkaitan dengan pekerjaan menjadi lebih baik dan efektif. ${ }^{16}$ Jenis pelatihan yang pernah diikuti seseorang yang berhubungan dengan bidang pekerjaannya akan dapat memengaruhi keterampilan dan sikap mentalnya akan meningkatkan kepercayaannya pada kemampuan dirinya, hal ini tentu akan berpengaruh positif terhadap kinerja karyawan yang bersangkutan. Pendapat Hasibuan "dengan pengembangan sumber daya manusia, maka diharapkan produktifitas kerja akan meningkat, kualitas dan kuantitas produksi semakin baik, karena keterampilan teknis dan keterampilan manajemen sumber daya manusia yang semakin baik". Sehingga pembimbing klinik yang telah mengikuti pelatihan asuhan persalinan normal memiliki keterampilan yang baik dalam asuhan persalinan normal sehingga dalam melakukan bimbingan terhadap mahasiswa khususnya keterampilan klinik asuhan persalinan normal tercapai dengan baik. Simpulan karakteristik demografi dan kualitas pembimbing klinik berhubungan dengan keterampilan klinik mahasiswa dalam asuhan persalinan normaldan pelatihan pembimbing klinik merupakan faktor yang paling berperan dalam keterampilan klinik asuhan persalinan normal.

\section{Simpulan}

Penelitian ini memberikan simpulan bahwa terdapat hubungan karakteristik pembimbing klinik dengan keterampilan klinik mahasiswa dalam asuhan persalinan normal. Dengan demikian dalam menentukan lahan praktik harus memperhatikan karakteristik pembimbing klinik yang ada pada lahan praktik.

\section{Daftar Pustaka}

1. Kementerian Kesehatan RI. Kurikulum Inti Pendidikan Diploma III Kebidanan. Jakarta: Badan Pengembangan dan Pemberdayaan SDM Kesehatan; 2011.

2. Dr. Supriyantoro SP, MARS. Kebijakan Kementrian Kesehatan Dalam Penyediaan Lahan Praktik Klinik Untuk Pendidikan Bidan di Indonesia Bandung: Kementrian Kesehatan RI; 2011.

3. Yanti WH, editor. OSCA Panduan Praktis menghadapi UAP D III Kebidanan. Yogyakarta: Mitra Cendikia; 2008.

4. Retnaningsih E. Pengaruh Faktor Perilaku Layanan Kesehatan Ibu Hamil Terhadap Kematian Ibu di Empat Kabupaten/Kota di Provinsi Sumatera Selatan, Buletin Penelitian Kesehatan.37(2),2009:67-78

5. Lulianthy E, Sutisna M, Sabarudin U. Perbandingan Tingkat Kelulusan Uji Kompetensi Berdasarkan Asal Institusi Pendidikan Kebidanan di Majelis Tenaga Kesehatan Provinsi Jawa Tengah Tahun 2010. Jurnal Pendidikan Bidan.2010

6. JNPK-KR DKRI. Pelatihan Klinik Asuhan Persalinan Normal. Jakarta2008.

7. Departemen Kesehatan RI. Standar Pembelajaran Praktik Kebidanan. Jakarta: Pusat Pendidikan Tenaga Kesehatan; 2006.

8. Resnayati Y. Faktor Determinan Pengalaman Belajar Klinik Keperawatan Medikal Bedah pada Mahasiswa DIII Keperawatan.

9. Firoozeh Firoozehchian ZTE, Ideh Dadgaran. Nursing-Midwifery Students and teachers' views of effective factors in clinical education. 2012;47:1832-7.

10. J G. Preparation for teaching in clinical setting Handbook of teaching for physical therapist ed. Boston1997.

11. Moore ML PJ. Clinical Education in physical therapy: present status/future needs:final report of the project on clinical education in physical therapy. Alexandria,VA: American Physical Therapy Association, section E;1976.

12. Fu-in Tang P, RN; Shieu-ming Chou, DSN, Hsien-hsien Chiang, MSN, RN. Student Perception of Effective and Ineffective Clinical Instructors. 2005;44(4)

13. Knox JEM, J. Important Clinical Teacher Behaviors as Perceived By University Nursing Faculty,Student and Graduates. Journal of advanced nursing. 1985;10:25-30.

14. Cook LJ. Inviting Behaviors of Clinical Faculty and Nursing Student Anxiety. Journal of Nursing Education. 2005;44:156-61.

15. Emery MJ. Effectiveness of the clinical instructors: students' perspective. Journal of physical therapy education. 1984;64(7). 
Kurniawati : Hubungan Karakteristik Pembimbing Klinik Dengan Keterampilan Klinik Asuhan Persalinan Normal Pada Mahasiswa Program Diploma III Kebidanan

16. Limisran. Faktor-faktor yang mempengaruhi kinerja pembimbing klinik AKPER Sapta Karya di Rumah Sakit Dr. Mohammad Hoesin dan Rumah Sakit Islam Siti Khadijah Palembang Tahun 2009. 2009. 